\title{
The European Commission's entrepreneurship and the social dimension of the European Semester: from the European Pillar of Social Rights to the Covid-19 pandemic
}

\author{
Patrik Vesan $^{1} \cdot$ Francesco Corti $^{2,3} \cdot$ Sebastiano Sabato $^{4}$
}

Accepted: 23 November 2020 / Published online: 16 January 2021

๑) The Author(s), under exclusive licence to Springer Nature Limited part of Springer Nature 2021

\begin{abstract}
This article reconstructs the role of European Commission President's political entrepreneurship in the further socialisation of the European Semester. Firstly, it analyses the context in which Juncker promoted the European Pillar of Social Rights. Secondly, it presents how such an initiative was mainstreamed into the Semester. Finally, by distinguishing among social retrenchment, social investment and social protection prescriptions, it analyses whether the post-2015 development of the Semester was consistent with Juncker's political effort. We find clear evidence of entrepreneurial activities in the strategic recourse to Presidency's Cabinet and the Secretary General and in the introduction of a new Social Scoreboard. Furthermore, we show that such socialisation process is congruent to the expected impact of European Pillar of Social Rights, which indeed contributes to strengthen an already ongoing incremental trend. Our analysis contributes to better qualify the socialisation process by highlighting its characteristics and the role of politics. These findings are particularly important to understand whether the Social Pillar left a legacy to the current Commission's social agenda and to the EU responses to the Covid-19 pandemic, and whether these changes open a new window of opportunity to further reform the Semester.
\end{abstract}

Keywords European Commission · European Semester · European Pillar of Social Rights $\cdot$ Social Europe $\cdot$ Entrepreneurship

Patrik Vesan

p.vesan@univda.it

Extended author information available on the last page of the article 


\section{Introduction}

Over the past decade, political parties in many Member States, especially those severely hit by the recession and austerity measures, have increasingly blamed the European Union (EU) as one of the causes of national socio-economic strains. This mounting dissensus is not a new phenomenon (Hooghe and Marks 2009) and, among other things, is linked to the contentious relationship between the European integration process and welfare states (Ferrera 2017). Since the 1990s, welfare states have gradually transformed into parts of a multi-tiered system of social policy, partially losing their sovereignty and autonomy (Leibfried and Pierson 1995). With the adoption between 2011 and 2013 of the 'Six Pack' and 'Two Pack', the two legislative packages aimed to strengthen the Stability and Growth Pact (SGP), the new EU post-crisis economic governance architecture marked a quantum leap in the EU's attempt to affect national decision-making processes (de la Porte and Heins 2015). A case in point is the creation of the European Semester (henceforth the Semester), the EU annual cycle of fiscal and economic policy coordination based on the 'back and forth' scrutiny and intervention in the management of national budgets, the threat of financial penalties, and the adoption of country-specific recommendations (CSRs). According to many scholars, the creation of the Semester has not only deepened the EU influence on national social and employment policies, but it has reinforced the subordination of social goals to the imperatives of economic competitiveness and fiscal discipline at the EU level (Dawson 2018; Costamagna 2018; Jordan et al. 2020).

This argument has been challenged by Zeitlin and Vanhercke (2018) who have supported the thesis of a gradual 'socialisation' of the Semester, i.e. a growing emphasis on social objectives and an enhanced role for the so-called social actors in the EU cycle of the process. Similarly, Bekker (2018) and Clauwaert (2018) have observed an increase-over the years-in the number of CSRs in the field of employment and social policies. According to Miró (2020), this has occurred in a context of progressive flexibilisation of the EU fiscal framework, which culminated in the temporary relaxation of the SGP rules after the outbreak of the Covid-19 crisis.

This article enters in this debate to delve into the politics of the socialisation of the Semester by highlighting the role of the European Commission (EC) Presidency within the EU coordination of national social and employment policies. Such a focus appears particularly interesting in the light of a more general dynamic of centralisation of power in the hands of the Presidency that characterised the Juncker Commission (Kassim and Laffan 2019) and that-we argue-has significantly affected the adoption and implementation of its flagship initiative in the social domain: the European Pillar of Social Rights (EPSR). The latter is a 'programmatic document' (Garben 2019) aimed at steering a renewed process of upward social convergence in the EU. Since the Commission made it immediately clear that 'the European Semester will be the main instrument for delivering on the Pillar' (Thyssen 2017), it is fair to say that the adoption of the EPSR has raised expectations of significant changes in the EU coordination of national economic and social policies. 
This article presents one of the first empirical studies investigating whether and to what extent there has been a 'Social Pillar' effect on the Semester and whether this can be related to the activism of Juncker. ${ }^{1}$ Our main argument is that the EU coordination of national social and employment policies, which remains a highly technical evidence-based process, can be affected by intentional political actions. To develop this argument, we first provide a framework for the analysis of Juncker's activism in promoting social issues and we reconstruct the strategy adopted by the Commission's President in this respect. We look at whether and how such an activism-eventually resulting in the elaboration and Interinstitutional Proclamation of the EPSR - has re-oriented the Semester in a way consistent with Juncker's political efforts. To this end, we propose an original classification of the CSRs, which distinguishes three types of prescriptions: social retrenchment, social investment and social protection prescriptions. This classification allows us to better qualify the development of the social dimension of the Semester over the cycles and understand if such development has been consistent with the entrepreneurship effort carried out the President of the EC. By checking the consistency between the direction of the entrepreneurial effort and the orientation of social policy prescriptions, our intent is not to exclude other causal factors that indeed may influence the development of CSRs but rather to provide a 'congruence test' (George and Bennett 2005; Blatter and Blume 2008) that can reinforce the internal validity of our causal inference.

The article proceeds as follows. 'Policy entrepreneurship and the socialisation of the Semester' section presents the theoretical framework that we use as a heuristic framework to frame our data collection and guide our investigation. 'Juncker's entrepreneurship in the EU social domain' section reconstructs Juncker's entrepreneurship in the EU social policy-making and how this was translated in the Semester. 'The European Pillar of Social Rights as a "turning point" of the Semester?' section presents our new classification of the CSRs in the domain of social and employment policies and the development of the social dimension of the Semester from 2011 to 2019. 'Discussion and conclusions' section discusses the main findings and concludes.

\section{Policy entrepreneurship and the socialisation of the Semester}

Different arguments have been used to explain the gradual socialisation of the Semester.

Firstly, Crespy and Vanheuverzwijn (2017) claim that this dynamic can be explained by the fact that reforms addressed to budgetary cuts and labour market deregulation had already been adopted in the previous years. Secondly, by looking at the domain of pensions, Guidi and Guardianchich (2018) demonstrate that the drafting of the Semester recommendations, and thus its potential socialisation, depends on national socio-economic conditions, the impact of previous reforms and economic or demographic forecasts. The third explanation focuses on the strategic

\footnotetext{
1 See also Vanhercke (2020).
} 
agency, reflexive learning and creative adaptation by social and employment actors to the new institutional conditions of the Semester (Zeitlin and Vanhercke 2018). Finally, some scholars have focused on the politics of the Semester, for instance, by looking at the pressures exerted by trade unions, non-governmental organisations (NGOs), national parliaments and governments (Sabato et al. 2017; Hallerberg et al. 2017; Maricut and Puetter 2018). Zeitlin and Vanhercke (2018) stressed that the reorientation of the Semester towards social goals can be understood in light of the 'mounting pressure exerted by the EU-wide political debate on the social dimension of the EMU initiated by the President of the European Council, Herman Van Rompuy' (Ibidem, 161). Similarly, Copeland and Daly (2018) have underlined, among other factors, the efforts made by former Social and Employment Affairs Commissioner, László Andor, to promote a stronger 'market-correcting' approach in the Semester.

Diving in the above-mentioned debate on the political rationale of the Semester's socialisation process, this article focuses on a still underexplored chart, namely the role played by the EC President in affecting the EU socio-economic coordination process. Such a specific perspective is justified by the fact that-since Barroso, but especially under Juncker-the EC Presidency has progressively increased its capacity to steer the entire work of the Commission (Kassim et al. 2017) and, as a consequence, to guide the implementation of the EU socio-economic regime (Bauer and Becker 2014). In this respect, since the translation of the EPSR into the Semester was indicated as a priority by the Commission, it is of interest investigating how the Presidency has promoted the delivery of its objectives and the impact on the outputs of the Semester.

To explore how this capacity unfolds, this article draws on the literature on policy entrepreneurship (Kingdon 1995; Mintrom and Norman 2009; Ackrill et al. 2013). We contend that the EC President exerted an entrepreneurial activity within the Semester with the aim to introduce some innovations explicitly addressed to fulfil his political agenda. Such an entrepreneurial effort was realised in a context marked by the combination of three main 'streams' (Kingdon 1995) — the problem, the political and the policy stream - that led to the opening of a window for change. ${ }^{2}$ Notably, we claim that the coupling of the political and problem streams, i.e. the framing of problems realised in a specific political context, provided the EC President with some specific motives for action. These motives led to the elaboration of innovative policy solutions and strategies to support them, the key element of which was the promotion of a new reference framework for action, the EPSR. However, since our analysis concerns the Semester, i.e. an evidence-based process of policy coordination, this framework had to be translated into specific tools, practices and procedures. Put it differently, to be effective, the EPSR had to percolate into the language

\footnotetext{
2 The problem stream concerns the overall perception of the main problems that gets the attention of policy-makers and justifies the need for action. The political stream refers to factors such as governmental changes or legislative turnover that affect the plausibility for intervention. The policy stream concerns the solutions that decision-makers intend to adopt in a given context.
} 
of bureaucracy and the semantics of indicators in order to affect the EU coordination of national social and employment policies.

In the next sections, we firstly reconstruct the entrepreneurship process that led to the adoption of the EPSR and the subsequent changes in the Semester. To do so, we performed a content analysis of relevant EC's documents, triangulated with the findings from 26 in-depth semi-structured interviews with experts and elites within the Commission, the European Parliament (EP) and the Council as well as among social partners and non-governmental organizations. ${ }^{3}$ Secondly, we qualified the substantial development of the Semester by focusing on the policy orientation of social policy recommendations in order to test its congruence with EC President's entrepreneurial strategy.

\section{Juncker's entrepreneurship in the EU social domain}

\section{Problems, politics and solutions: towards the European Pillar of Social Rights}

When Juncker was appointed President of the Commission, the economic situation of the Union, despite some timid positive signals, remained worrisome (problem stream). In many Member States, especially in debtor countries, the social consequences of the euro crisis were perceived as a cost inflicted by the EU, as most of the austerity measures implemented at the national level were adopted under the 'shadow of hierarchy' of EU economic governance rules (Dawson 2018). The sluggish economic recovery and the mounting dissatisfaction towards the EU surely put the European project in political jeopardy. The legitimacy crisis of the Union and the adverse consequences of the austerity policies were well understood by the newly appointed president of the European Commission, Jean Claude Juncker, who in several occasion spoke about an EU 'polycrisis' (Zeitlin et al. 2019), and accordingly referred to his mandate as the 'last-chance Commission'. Against this backdrop, Juncker explicitly advocated for a new approach to address the scars left by the economic and social crisis and correct the mistakes made during the Great recession and claimed for the citizens 'left-behind' during the Great Recession a new central role in the EU agenda. As posit by Juncker in an interview released to Politico.eu ${ }^{4}$ :

If we, as the European Union, lose the support of the workers, of the working class, if workers feel left-behind because they are not considered in the same way as other societal forces are, then we will lose support for the European

Union as a whole.

At the same time, the Juncker Commission was formed after the 2014 European elections, which were marked by the sharp advancement of "non-mainstream EU parties' (Véron 2019) (political stream). The latter were strongly mobilised in

\footnotetext{
${ }^{3}$ For details about the interviews, see 'Appendix 1' section.

${ }^{4}$ See https://www.politico.eu/article/jean-claude-juncker-social-pillar-eu-identity-commission-welfarepolicy/.
} 
defence of national welfare states against the 'intrusiveness' of the EU institutions in domestic decision-making and present themselves as the defenders of those citizens' (social) rights that have been menaced by EU policies (see Manow et al. 2018; Zeitlin et al. 2019). Juncker explicitly warned against the risk of 'galloping populism', which indeed represented a threat not only for the EU policies but for the EU qua polity, ${ }^{5}$ and called for a prompt political response.

The call for such a response was further increased by the process that led to the appointment of Juncker as President of the Commission, i.e. the Spitzenkandidaten, which gave him a unique opportunity to claim stronger authority for the realisation of his political priorities such as the reinforcement of Europe's social dimension and of a sense of solidarity and social justice among EU citizens (Kassim and Laffan 2019). The reason why the 'social challenge' gained centrality in Juncker's agenda is twofold. On the one hand, his biography certainly played a significant role. Christian-democrat, with strong ties with the trade-unionism, Juncker has always exhibited political awareness and sensitivity to social issues. ${ }^{6}$ On the other hand, to be elected, Juncker needed the support of a majority also including the S\&D group in the EP (Nugent and Rhinard 2019). This led Juncker to promise to centre-left Members of the European Parliament a stronger engagement on European social policy during his mandate, for example by focusing on the revision of the posting of worker directive and assuring more social fairness in implementing structural reforms.

Altogether, both the problem and political streams provided Juncker the motives to justify the Commission's engagement in relaunching an ambitious social agenda (Vesan and Corti 2020). The EPSR, as a brand-new solution (policy stream), was inspired by a clear political rationale that even anticipated the definition of concrete goals:

At the beginning, no one, not even Juncker himself, when he launched the Pillar, was aware of what it would have become. This was a very political manoeuvre. He was trying to see where he could land by repeating the same message all over again and he managed to get an agreement on a political declaration with high visibility (DGECFIN2)

Juncker devoted much effort in promoting the EPSR, by launching a large public consultation and getting the political endorsement of both the European Parliament and of several Member States. In particular, he strongly profited from the help of Allan Larsson and Maria João Rodrigues ${ }^{7}$ in overcoming political vetoes and building a coalition of actors to support the EPSR (Vesan and Corti 2019).

The Interinstitutional Proclamation by the presidents of the Parliament, Council of the EU and Commission at the European Summit for Fair Jobs and Growth held

\footnotetext{
5 Schmidt (2019) convincingly uses the expressions 'politics against policies' and 'politics against polity'.

6 See, e.g. C. Stupp, Juncker is 'sincerely in favour of social Europe', Euractiv 17 November 2017.

7 Allan Larsson served as Director General for DG Employment, Social Affairs and Equal Opportunities in the European Commission between 1995 and 2000 and was one of the fathers of the European Employment Strategy. Maria João Rodrigues was Minister of Employment of Portugal (1995-1997) and is known as the 'mother' of the Lisbon Strategy.
} 
in Gothenburg in November 2017 gave to the EPSR a significant political leverage, much higher than other initiatives in the social domain previously undertaken such as the Social Investment Package (SIP).

What distinguishes the EPSR from the SIP, however, is not limited to the political resonance of the former. As stressed by Sabato and Corti (2018), an important difference consists in the adoption of a right-based approach to social policies, which partially departs from the approach to social policy as a 'productive factor' that characterised to a large extent the notion of social investment in the SIP. ${ }^{8}$ For instance, in the Communication on the EPSR following the public consultation process, the European Commission (2017:4) clearly highlighted that the Pillar was 'about delivering new and more effective rights for citizens', omitting any explicit references to social policy as a productive factor and to fiscal sustainability (Sabato and Corti 2018). As stated by an EU official we interviewed:

I think that there are 'philosophical' differences between the SIP and EPSR. The SIP was definitively fiscally more prudent and it tried to move towards a new type of social protection that is not necessarily similar to the one people use to call 'Social Europe'. The EPSR is a sort of turn-around, going back to this idea of social rights and entitlements. I remember these were things for which we had difficulties when we were working to the SIP, you know even trying to include words such as 'adequate income support', it was very difficult. While with the Pillar this is all over. So there are clearly different political philosophies behind the two initiatives [EMPL1].

As it emerges from our research, this focus on social rights was a direct consequence of Juncker's activism through its Cabinet and the Secretary General [SECGEN]. A number of interviews confirm this:

There was a fair amount of people inside the EC and DG EMPL who thought it was a bit uneasy working with the concept of rights. There was a sort of scepticism that we put too much expectation out there. It was the President Cabinet who put for much more ambitious document [...] The original proposal coming from DG EMPL was more cautious. This changed drastically at the President's Cabinet level and the emphasis was definitively put on rights, entitlements and principles. [EMPL2]

If you think again to active inclusion, social investment was very much about DG EMPL initiative. The Pillar was much more an idea of the President. Then of course, the big army in terms of resources is DG EMPL, but it was very much designed by SECGEN. [The] President's Cabinet was in the lead of the initiatives, attending the meetings of the working groups from the beginning. And the effect you see it in terms of visibility. The President has always put it forward and advertised it [SECGEN1].

\footnotetext{
${ }^{8}$ On the use of different 'social policy images' in the EC President's discourses on social policies, see also Vesan and Pansardi (2020).
} 
In addition to the shift in the approach to social policies from a productive factorbased narrative to a rights-based one, another important difference should be spelled out and concerns the policy issues on which the two initiatives focus. Indeed, compared to the SIP, the EPSR offers a broader understanding of social policies by emphasising a range of social rights mainly related to the sphere of fair working conditions and work transitions (included minimum wages, access to social protection for all), which were absent in the SIP (Sabato et al. 2017; Hemerijck and Corti 2020).

\section{From principles to implementation: Juncker's entrepreneurship within the Semester}

The simple proclamation of the EPSR would have been a merely symbolic solution, without the definition of concrete arrangements for its implementation. This holds particularly true for the Semester, a process with a strong bureaucratic component following an 'evidence-based' approach to decision-making (Zeitlin and Vanhercke 2018). In order to have an impact in this context, political priorities need to be translated into specific procedures and practices and supported by evidence, indicators and data.

In this respect, thanks to the centralisation of the authority in the hand of the EC Presidency and the enhancement of administrative capacity, Juncker made explicit use of his Cabinet and the SECGEN as personal 'armed arms' to reinforce the visibility of social issues in the Semester. Already at the beginning of its mandate, an internal note from the SECGEN was distributed to the Commission's 'country teams', which specified each DG's responsibilities regarding the drafting of the Country Report (CR). According to that note, DG EMPL oversees all the issues related to employment and social policies and it has the last word in any dispute that might arise on any aspect of the employment-related part of the Country Reports. Such choice was reinforced in 2015 by the decision of Juncker to move the unit 'Labour Market Policy and Training and Skills' from Directorate-General for economic and Financial Affairs (DG ECFIN) to DG EMPL. These novelties strengthened the autonomy of DG EMPL vis-à-vis DG ECFIN and, at the same time, increased the capacity of the Commission's officials in DG EMPL to provide evidence-based arguments and claim for more visibility for EU social and employment issues in the Semester (Vanhercke 2020).

In addition to this, the EC President supported the better use of socio-economic indicators within the Semester cycle by adding, in 2015, three indicators (activity rate, youth unemployment, long-term unemployment) to the existing 11 headline indicators of the Macroeconomic Imbalances Procedure (MIP) scoreboard (European Commission 2015), thus further strengthening the attempt to make social concerns more visible within the MIP initiated by former-Commissioner Andor 2 years before (Copeland and Daly 2018).

Yet, the most significant innovation occurred in 2017, after the adoption of the EPSR, which had a double impact on the Semester. On the one hand, the Pillar served as a new, concrete reference framework to justify further attention to social 
and employment issues in the process. As stated by our interviewees, during winter 2017 and 2018, notes and e-mails were exchanged between core DGs, where DG EMPL officials explicitly argued for the EPSR to become a major thread in the analyses carried out by the Commission (EMPL1, EMPL2, ECFIN4). On the other hand, the Commission proposed the adoption of a new Social Scoreboard, i.e. a set of indicators that feed into the Semester to monitor the implementation of the EPSR (see the online Appendix n. 1). Notably, it was again the EC Presidency, through the Secretary General, that played a major role in pushing for the introduction of this new monitoring tool already in the 2018 Semester. Actually, the Scoreboard came as a surprise for both the Council's Social Protection Committee (SPC) and Employment Committee (EMCO), which were puzzled by the proposal to immediately use it in the Joint Employment Report for the 2018 Semester cycle. As stressed by one of our interviewees:

The Scoreboard has not been the subject of any consultation process in advance of the launching of the Pillar. This was a kind of surprise. So, the ISG [SPC-Indicator sub-group], SPC and also the EMCO and its indicators group confronted at that moment with a situation where it was proposed to implement this new tool already in the upcoming Joint Employment Report of this year, while we did not have the opportunity to know about the contents, the purposes and the idea behind the Scoreboard. (SPC1).

The strong political pressure of Juncker in mainstreaming the EPSR in the early steps of the Semester 2018 gave leverage to EU officials, in particular the DG EMP, to claim greater consideration of social and employment challenges in the CRs. As revealed by one of our interviewees:

Imagine meetings between the 'core' DGs taking place one month after the adoption of the Social Pillar in Gothenburg. We are all people and we know what is going on. People that in that room want more emphasis on social and employment protection, what do they do? They say: Guys, we went to Gothenburg, we cannot ignore this. So, they have a strong argument to affect the balance in their favour. So not at the level of analysis, which in the case of employment and social affairs is more or less stable in these years. But in the way the analysis is given weight inside the documents. The difference is that the Gothenburg Proclamation gives you a good political argument to claim for more space. (ECFIN2)

Beyond EC officials' statements, evidence of the use of the Scoreboard in the 2018 Semester cycle emerges immediately in the Semester's AGS, the Employment Guidelines, in the 'Executive summary' of the CRs and in the subsection on 'Economic situation and outlook', which are the sections where the Commission indicates its political priorities for each Member States. ${ }^{9}$ For instance, in the AGS 2018, particular attention was paid to defining themes of the EPSR such as

\footnotetext{
${ }^{9}$ For a different view on the implementation of the EPSR through the Semester, see Rasnača and Theodoropoulou (2020).
} 
social protection and inclusion to tackle inequality and poverty, adequacy of pension system and equal and affordable access to healthcare and long-term care (Hacker 2019; Sabato and Corti 2018). Similarly, the new Employment Guidelines present a focus on accessibility and quality of services and pay a specific attention to social inclusion of disadvantaged groups. As regards the CRs, a new 'Social Pillar box' was introduced in 2018, which presents the Member States' socio-economic performances monitored on the basis of the headline indicators of the Social Scoreboard.

As posit by one of our interviewees, the introduction of the Scoreboard was a central step in embedding the EPSR in the Semester, since it increased the visibility to social challenges and 'contributed to making the social side of the Semester more structured and methodical' (EC2). This claim was also confirmed by another EU official from the DG ECFIN:

What happened in one of those meetings at the beginning of the 2018 Semester cycle is that DG EMPL simply said: we need a box in the Country reports on the Social Pillar. And we (DGECFIN) accepted it because it was a clear political instruction from the President Cabinet. Two months later, when we were drafting the CSRs, they said that we need to take into account the political visibility (given by the box), which should have been translated also into the CSRs. You build on the visible milestones that then become a path (DGECFIN2, italics added).

Against this backdrop, the next section investigates whether Juncker's entrepreneurship within the Semester through the EPSR led to a consistent change also in the main outputs of the process: the CSRs.

\section{The European Pillar of Social Rights as a 'turning point' of the Semester?}

To understand whether and to what extent there has been an impact of the EPSR on the Semester's country-specific recommendations, we performed a manual content analysis of 991 CSRs from 2011 to 2019. First, we classified all CSRs into two main groups: social CSRs and other CSRs. Social CSRs refer to the recommendations in the following areas: employment policy, education and training policy, equality policy, health and long-term care, pensions, poverty and social exclusion (see also Copeland and Daly 2018). Second, since each CSRs can contain more than one policy prescription, we divided each CSR in 'sub-recommendations', thus identifying 1076 policy prescriptions. ${ }^{10}$ Third, drawing on Hemerijck's classification of welfare policy paradigms (Hemerijck 2018), we categorised these prescriptions into three groups, which point to three different policy orientations: the social retrenchment, the social investment and the social protection prescriptions.

In accordance with the 'neoliberal welfare paradigm' (Hemerijck 2018), social retrenchment prescriptions primarily focus on the goal of fiscal sustainability of

${ }^{10}$ For a similar approach, see Crespy and Vanheuverzwijn (2017), Guidi and Guardianchich (2018).

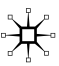


social policies. These prescriptions typically envisage the retreat of the State as the key provider of social solidarity in terms of both benefits and social rights and involve the adoption of 'retrenchment' measures, such as social benefit curtailment, cost-containment strategies, labour market deregulation or pension privatisation. Social protection prescriptions instead suggest increasing the public support to protect individuals against 'old social risks' ${ }^{11}$ (e.g. unemployment, health diseases, age-related needs), extending employment-protection legislation and improving working conditions (included wages and social dialogue), in line with the traditional 'Keynesian-Beveridgean' paradigm (Hemerijck 2018). Finally, social investment prescriptions also ask for an increase in welfare expenditures, but they primarily focus on the protection from 'new social risks' and the promotion of 'wellbeing returns' by supporting human-capital enhancement policies and measures addressed to reinforce the employability of specific groups, such as young people, women and elderly workers. Table 1 provides some examples of our coding scheme.

Contrary to previous attempts that focus only on the analysis of the content of the CSRs (Crespy and Vanheuverzwijn 2017; Copeland and Daly 2018), each potentially ambiguous prescription was checked against the background information provided in the recitals that introduce the CSR and, if necessary, the related Country Report. ${ }^{12}$ In this sense, our analysis also considers the background evaluation made by EU officials. Table 1 provides some examples of our coding scheme.

While denoting some continuity with previous classifications of CSRs developed in the literature on the Semester, our proposal provides a finer grained understanding of the social dimension of the CSRs, which is more suitable for detecting possible changes linked to Juncker's entrepreneurial activity and to the EPSR. Notably, the distinction between social retrenchment prescriptions, one the one hand, and 'expansive' social policy prescriptions (i.e. social protection and social investment recommendations), one the other hand, reflects a change in the level of public intervention in this domain and, consequently, in the paradigmatic approach ( $a$ la Hemerijck 2018) to social policies (see also Haas et al. 2020). In this respect, our first expectation is that Juncker's call for reinforcing the social dimension of the EU Semester would be accompanied by a sharp drop in social retrenchment prescriptions. At the same time, the distinction between social investment and social protection prescriptions helps us to understand whether the potential increase in 'expansive' social CSRs was only led by an increase in social investment prescriptions, in line with the SIP, or also by a positive trend in social protection recommendations, as foreseen by the underlying philosophy of the EPSR (cf. 'Problems, politics and solutions: towards the European Pillar of Social Rights' section).

This said, our analysis of the social CSRs has also an important limitation: we do not explore neither the content of the recommendations outside the social domain

\footnotetext{
11 On the distinction between old and new social risks, see, e.g. Armingeon and Bonoli (2007).

12 If the policy orientation was still uncertain, we adopt a conservative approach by including it into a 'grey' category. Nevertheless, our 'grey' social prescriptions are equal to $8.3 \%$ of the total prescriptions, compared to mixed-CSRs category identified by Copeland and Daly (2018), which amounts to $52 \%$ of the total share of CSRs.
} 


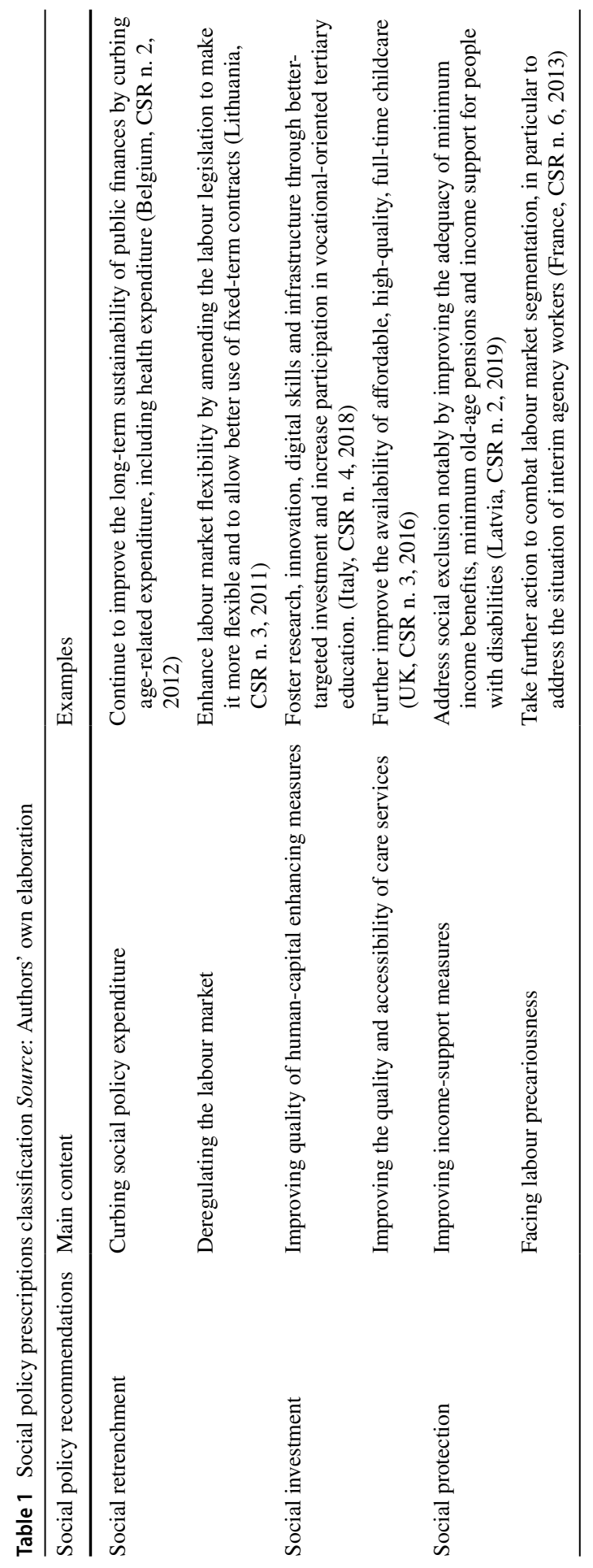

s. 


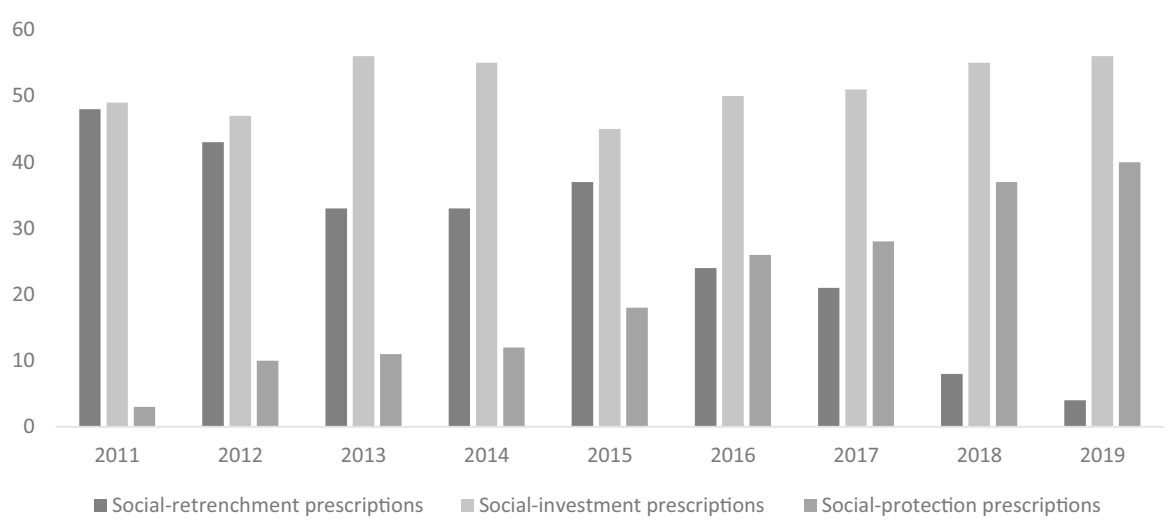

Fig. 1 The internal composition of the Semester's social recommendations. Source: Authors' own elaboration. Note: percentage of policy prescriptions by 'orientation' over the total of social recommendations

(e.g. macroeconomic recommendations and taxation recommendations) nor the overall coherence of the set of CSRs addressed to individual countries, both aspects that may have important implications for Member States' compliance with social CSRs. In this respect, recent studies have highlighted the potential tensions between social and non-social recommendations, notably in countries with high public debts (Hacker 2019; Haas et al. 2020; Antonucci and Corti 2020). This limitation, however, does not diminish the value of our analysis, which is focused on the political processes leading to changes in the orientations of the Semester towards social issues. At the same time, our objective is to look at the Semester's recommendations evolution at the aggregated level and not on the implications for specific Member States. Nevertheless, we acknowledge that it would be necessary to strengthen the links between 'macro-level' analyses of the CSRs and analyses focusing on specific countries, groups of countries or, even, specific policy issues (cf. Jordan et al. 2020).

Figure 1 shows the internal composition of social policy prescriptions from the first Semester cycle until the last one under the Juncker Commission (2019). Three main trends emerge. First, as expected, a sharp reduction in social retrenchment prescriptions, which decrease over the years from $48 \%$ in 2011 to $4 \%$ in the 2019 cycle. Second, and almost reflecting the social retrenchment prescriptions' trend, significant and steady increase in social protection prescriptions, which grew incrementally from $3 \%$ in 2011 to $40 \%$ in the 2019 cycle. Finally, we observe a relative stability of social investment prescriptions, with an increase in the 2013 cycle, followed by a decrease in 2015 and then a 'catching up' phase in the last cycles.

Overall, if we look at the trend from 2011 to 2019, the internal composition of the social dimension of the Semester has radically changed. Nevertheless, this change has been marked by the reinforcement and consolidation of ongoing trends, rather than by some sharp 'U-turns'. At a first glance, this incremental trend seems partially disconfirm the thesis of a 'Social Pillar effect' on the development of the socialisation process. However, it is possible to observe that, while the share of social protection prescriptions remained relatively constant in the 2012-2014 cycles, 
from 2015 to 2019, such a share has more than doubled (+122\%), with a significant rise in the last two cycles, i.e. after the inclusion of the Scoreboard in the Semester. In the same period (2015-2019), social investment prescriptions also increased, but at a slower pace $(+24.4 \%)$. Therefore, it is fair to say that the growth in expansive social policy recommendations can be mainly attributed to social protection prescriptions. Finally, as we expected, social retrenchment recommendations have strongly diminished since 2015 , and notably in $2018 .^{13}$

In conclusion, although the incremental development is indeed the consequence of several-often country specific-factors, our tripartite classification allows us to better qualify the overall trend in the socialisation of the Semester and ascertain its congruence with Juncker's entrepreneurship effort.

\section{Discussion and conclusions}

This article contributes to the literature on the European Semester highlighting the entrepreneurial role of the EC Presidency and its impact on the social dimension of the Semester. Firstly, it provides a reconstruction of the political context in which Juncker implemented its entrepreneurial strategy eventually resulting in the elaboration of the innovative 'solution' of the EPSR. Secondly, it presents how such a solution was mainstreamed into the Semester and, finally, by developing an original tripartite classification of social policy prescriptions, it analyses whether the key outputs of the Semester (the CSRs) were consistent with Juncker's political effort.

In a context characterised by the rise of anti-European movements and multiple EU crises that question the legitimacy of the EU, the entrepreneurship of Juncker contributed to open a window of opportunity to increase the visibility of social issues within the Semester. To this end, Juncker promoted the launch of the EPSR, which provided a reference framework for all the EC initiatives in the domain of social policy. In this respect, clear evidence of these entrepreneurial activities can be found in the recourse to the strategic use of Presidency's Cabinet and the Secretary General, the re-organization of tasks within DG EMPL and DG ECFIN and, crucially, the adoption of a new monitoring tool, i.e. the EPSR Social Scoreboard. Our research shows that the window of opportunity opened by Juncker did not produce an abrupt change in the internal composition of the social dimension of the Semester but, rather, a reinforcement and consolidation of an ongoing trend.

Notably, we observe that the socialisation process has been further institutionalised after the introduction of the Social scoreboard. Second, in the most recent Semester cycles (2018-2019), such a socialisation was characterised-besides a decrease of social retrenchment prescriptions-by a strong increase in social protection recommendations, a trend that is in line with Juncker's entrepreneurial activity in the EU social domain. As a result, in recent years the socialisation process has

\footnotetext{
13 This is also due to the improvement of the economic situation. The EU unemployment rate in 2018 was at its lowest level ever recorded.
} 
started to exhibit a more balanced mix between social investment and social protection prescriptions.

Against this background, the question is how long the window of opportunity opened up by Juncker will last in the years to come. ${ }^{14}$ In this respect, it seems that the activism of Juncker, while not producing a path breaking effect on the social outputs of the Semester, has nonetheless left a strong legacy to the von der Leyen Commission. Indeed, in the framework Semester 2020, permeated on the priorities of the Commission's European Green Deal and 'refocussed' to integrate the United Nations' Sustainable Development Goals, the Pillar is expected to be the key reference framework to ensure a socially fair 'green transition' (European Commission 2020). A look at the CSRs 2020 unveils an interesting scenario. Indeed, the high concentration of recommendations on extending the coverage of social security systems, activating automatic stabilisers, strengthening healthcare systems, reestablishing well-functioning social dialogue relationships and reskilling workers, all show a focus of the Commission in what we call the social protection recommendations (Rainone 2020). At the same time, already on 5 February 2020, the Commission released a Communication on 'Economic governance review', in which it clearly sets out the limits of the current EMU framework, especially by pointing out its incapacity to take due account of the social developments and challenges. On top of this, the adoption of the new Recovery and Resilience Facility (RRF) ${ }^{15}$ directly links the EU support after pandemic to the social objectives set out in the Semester country-specific recommendations and uses the Social Scoreboard as the benchmark that the Commission will use to assess the national recovery plans presented by Member States. In conclusion, the Covid-19 pandemic crisis may represent a new window of opportunity for the Commission, as policy entrepreneur, to further reform the Semester. Whether this will also contribute to a further strengthening of the Semester's social dimension remains an open question and the 'proof of the puddling will be in the eating,. ${ }^{16}$

\section{Appendix 1: List of interviewees}

We made two rounds of interviews. The first round of the interviews was focused on the characteristics of the Semester process and its internal dynamics (in 2015-2017, 7 interviews), while the second round (in 2018-2019, 18 interviews) was addressed to the specific trends in social policy prescriptions. The authors are thankful to Pierre Vanheuverzwijn, who shared with us the interviews realised in the first round.

\section{ECFIN1: European Commission, DG ECFIN, Brussels, July 2015}

\footnotetext{
14 On the importance of policy window in terms of its size and duration, see Keeler (1993) and Ackrill et al. (2013).

15 The RRF is the temporary recovery instrument puts at the centre of the 'Next Generation EU' programme.

16 We thank the anonymous reviewer for this closing suggestion.
} 
2. ECFIN2: European Commission, DG ECFIN, Brussels, December 2018

3. ECFIN3: European Commission, DG ECFIN, Brussels, September 2015

4. ECFIN4: European Commission, DG ECFIN, Brussels, May 2018

5. ECFIN5: European Commission, DG ECFIN, Brussels, April 2018

6. EMCO1: Employment Committee, Brussels, April 2018

7. EMCO2: Employment Committee, Brussels, October 2018

8. EMPL1: European Commission, DG EMPL, Brussels, April 2018

9. EMPL2: European Commission, DG EMPL, Amsterdam, October 2018

10. EMPL3: European Commission, DG EMPL, Brussels, January 2018

11. EMPL4: European Commission, DG EMPL, Brussels, April 2015

12. EMPL5: European Commission. DG EMPL, Brussels, December 2015

13. $\mathrm{EC}^{+}$: European Commission, Brussels, November 2018

14. $\mathrm{EC}^{+}$: European Commission, Brussels, November 2018

15. $\mathrm{EC}^{+}$: European Commission, Brussels, September 2015

16. $\mathrm{EC}^{+}$: European Commission, Brussels, January 2017

17. SPC1: Social Protection Committee, Brussels, January 2018

18. SPC2: Social Protection Committee, Brussels, October 2018

19. EPC1: Economic Policy Committee, Brussels, February 2016

20. EPC2: Economic Policy Committee, Brussels, June 2015

21. EFC1: Economic and Financial Committee, Brussels, April 2018

22. EFC2: Economic and Financial Committee, Brussels, May 2018

23. EP1: European Parliament's Rapporteur on the Social Pillar, Brussels, May 2018

24. ETUC1: ETUC Confederal Secretary, Brussels, February 2018

25. SP1: Social Platform, Brussels, January 2018

26. COMM1: Former Commissioner Social and Employment Affairs, February 2019

Note: ${ }^{+}$The interviewed person explicitly asks to not reveal the internal unit of the European Commission to which she/he belongs.

\section{References}

Ackrill, R., A. Kay, and N. Zahariadis. 2013. Ambiguity, multiple streams, and EU policy. Journal of European Public Policy 20 (6): 871-887.

Antonucci, L., and F. Corti. 2020. Inequalities in the European Semester. Brussels: Foundation for European Progressive Studies (FEPS).

Armingeon, K., and G. Bonoli (eds.). 2007. The politics of post-industrial welfare states: Adapting postwar social policies to new social risks. London: Routledge.

Bauer, M., and S. Becker. 2014. The unexpected winner of the crisis: The European Commission's strengthened role in economic governance. Journal of European Integration 36 (3): 213-229.

Bekker, S. 2018. Flexicurity in the European Semester: Still a relevant policy concept? Journal of European Public Policy 25 (2): 175-192.

Blatter, J., and T. Blume. 2008. In search of co-variance, causal mechanisms or congruence? Towards a plural understanding of case studies. Swiss Political Science Review 14 (2): 315-356. 
Clauwaert, S. 2018. The country-specific recommendations (CSRs) in the social field. An overview and comparison. Update including the CSRs 2018-2019. Brussels: ETUI Background Analysis.

Copeland, P., and M. Daly. 2018. The European Semester and EU Social Policy'. Journal of Common Market Studies 56 (5): 1-18.

Crespy, A., and P. Vanheuverzwijn. 2017. What "Brussels"' means by structural reforms: Empty signifier or constructive ambiguity? Comparative European Politics 17 (1): 1-20.

Costamagna, F. 2018. National social spaces as adjustment variables in the EMU: A critical legal appraisal. European Law Journal 24 (2-3): 163-190.

Dawson, M. 2018. New governance and the displacement of Social Europe: The case of the European Semester. European Constitutional Law Review 14 (1): 191-209.

de la Porte, C., and E. Heins. 2015. The Sovereign Debt Crisis, the EU and Welfare State Reform. Comparative European Politics 13 (1): 1-7.

European Commission. 2015. Adding employment indicators to the scoreboard of the Macroeconomic Imbalance Procedure to better capture employment and social development. Available at: https:// ec.europa.eu/info/sites/info/files/employment_indicators_mip_en.pdf.

European Commission. 2017. Communication from the Commission to the European Parliament and the Council. Establishing a European Pillar of Social Rights. COM (2017) 250 final. Brussel.

European Commission. 2020. Communication from the Commission to the European Parliament and the Council. A strong social Europe for just transitions. COM (2020) 14 final. Brussel.

Ferrera, M. 2017. The Stein Rokkan lecture 2016 mission impossible? Reconciling economic and social Europe after the euro crisis and Brexit. European Journal of Political Research 5 (6): 3-22.

Garben, S. 2019. The European pillar of social rights: An assessment of its meaning and significance. Cambridge Yearbook of European Legal Studies 21: 101-127.

George, A.L., and A. Bennett. 2005. Case study and theory development in the social sciences. Cambridge, MA: MIT Press.

Guidi, M., and I. Guardianchich. 2018. Intergovernmental or supranational integration? A quantitative analysis of pension recommendations in the European Semester. European Union Politics 19 (4): 684-706.

Hacker, B. 2019. A European Social Semester? The European Pillar of Social Rights in practice. Brussels: ETUI Research Paper.

Hallerberg, M., B. Marzinotto, and G.B. Wolff. 2017. Explaining the evolving role of national parliaments under the European Semester. Journal of European Public Policy 25 (2): 250-267.

Haas, J.S., V.J. D'Erman, D.F. Schulz, and A. Verdun. 2020. Economic and fiscal policy coordination after the crisis: Is the European Semester promoting more or less state intervention? Journal of European Integration 42 (3): 327-344.

Hemerijck, A. 2018. Social investment as a policy paradigm. Journal of European Public Policy 25 (6): $810-827$.

Hemerijck, A., and F. Corti. 2020. Social Europe after the Great Recession: From an initial 'conservative reflex' to a new 'policy momentum'. Paper presented at ESPAnet Italy General Conference.

Hooghe, L., and G. Marks. 2009. A post-functionalist theory of European integration: From permissive consensus to constraining dissensus. British Journal of Political Science 39 (1): 1-23.

Jordan, J., V. Maccarrone, and R. Erne. 2020. Towards a Socialisation of the EU's New Economic Governance Regime? EU Labour Policy Interventions in Germany, Ireland, Italy and Romania (20092019). British Journal of Industrial Relations, online version.

Kassim, H., and B. Laffan. 2019. The Juncker Presidency: The 'Political Commission' in Practice. Journal of Common Market Studies 57 (1): 49-61.

Kassim, H., S. Connolly, R. Dehousse, O. Rozenberg, and S. Bendjaballah. 2017. Managing the house: The Presidency, agenda control and policy activism in the European Commission. Journal of European Public Policy 24 (5): 653-674.

Keeler, J.T. 1993. Opening the window for reform: Mandates, crises, and extraordinary policy-making. Comparative Political Studies 25 (4): 433-486.

Kingdon, J.W. 1995. Agenda, alternatives and public policy. Boston: Little, Brown.

Leibfried, S., and P. Pierson. 1995. The semi-sovereign welfare states: Social policy in multi-tiered Europe. In Fragmented social policy: The European union's social dimension in comparative perspective, ed. S. Leibfried and P. Pierson, 43-77. Washington: Brookings Institution.

Manow, P., B. Palier, and H. Schwander. 2018. Welfare democracy and party politics. Oxford: Oxford University Press. 
Maricut, A., and U. Puetter. 2018. Deciding on the European Semester: The European Council, the Council and the Enduring Asymmetry between Economic and Social Policy Issues. Journal of European Public Policy 25 (2): 193-211.

Miró, J. 2020. Austerity's failures and policy learning: Mapping European Commission officials' beliefs on fiscal governance in the post-crisis EU. Review of International Political Economy, online version.

Mintrom, M., and P. Norman. 2009. Policy entrepreneurship and policy change. Policy Studies Journal 39 (4): 649-667.

Nugent, N., and M. Rhinard. 2019. The 'political' roles of the European Commission. Journal of European Integration 41 (2): 203-220.

Rainone, S. 2020. The country-specific recommendations (CSRs) in the social field. An overview and comparison. Update including the CSRs 2020-2021. Brussels: ETUI.

Rasnača, Z., and S. Theodoropoulou. 2020. EMU and the European Pillar of Social Rights: Do (Shall) the Twain Ever Meet? Politiche Sociali/Social Policies 2 (2020): 331-354.

Sabato, S., and F. Corti. 2018. The times they are A-Changin'? The European Pillar of social rights from debates to reality check. In Social Policy in the European Union: State of the play 2018, ed. B. Vanhercke, D. Ghailani, and S. Sabato, 51-70. Brussels: European Social Observatory and European Trade Union Institute.

Sabato, S., B. Vanhercke, and S. Spasova. 2017. Listened to, but not heard? Social partners' multilevel involvement in the European Semester. Brussels: OSE Research Paper.

Schmidt, V. 2019. Politicization in the EU: Between national politics and EU political dynamics. Journal of European Public Policies 26 (7): 1018-1036.

Thyssen, M. 2017. Speech at EPSCO Council meeting 7 December. Available at: https://video.consilium. europa.eu/en/webcast/91daff98-d15b-493e-a17c-e1433a7bbcf1.

Vanhercke, B. 2020. From the Lisbon strategy to the European Pillar of Social Rights: The many lives of the Social Open Method of Coordination. In Social policy in the European Union 1999-2019: The long and winding road, ed. B. Vanhercke, D. Ghailani, S. Spasova, and P. Pochet. Brussels: OSE ETUI.

Véron, N. 2019. The European Parliament elections results: The long view, Bruegel blog. https://www. bruegel.org/2019/05/european-parliament-election-results-the-long-view/.

Vesan, P., and F. Corti. 2019. New tensions over Social Europe? The European Pillar of Social Rights and the Debate within the European Parliament. Journal Common Market Studies 57 (5): 977-994.

Vesan, P., and F. Corti. 2020. The return of the European Commission's social entrepreneurship and the legacy of the European Pillar of Social Rights, paper presented at the XIII ESPANET-Italia conference, Venezia.

Vesan, P., and P. Pansardi. 2020. Speaking Social Europe: A paradigmatic shift in the European Commission Presidents' policy discourse. Journal of European Social Policy, online first.

Zeitlin, J., and B. Vanhercke. 2018. Socializing the European Semester: EU social and economic policy co-ordination in crisis and beyond. Journal of European Public Policy 25 (2): 149-174.

Zeitlin, J., F. Nicoli, and B. Laffan. 2019. Introduction: The European Union beyond the polycrisis? Integration and politicization in an age of shifting cleavages. Journal of European Public Policies 26 (7): 963-976.

Disclaimer The authors disclosed receipt of the following financial support for the research, authorship and/or publication of this article: This article has been written in the context of the REScEU project (Reconciling Economic and Social Europe, www.resceu.eu), funded by the European Research Council (grant no 340534).

Publisher's Note Springer Nature remains neutral with regard to jurisdictional claims in published maps and institutional affiliations.

Prof. Patrik Vesan is associate professor in Political Science at the University of Aosta Valley (Italy). His main research interests focus on the EU social policies and the Italian labour market policies in comparative perspective. 
Dr. Francesco Corti is postdoctoral researcher at the department of political and social science of the University of Milan and associate researcher at the Centre for European Policy Studies. Expert in European social and employment policies and EU economic governance with 4 years of professional experience, Francesco provided research and advisory services to various Brussels-based think tanks and EU institutions, included the European Commission, the European Parliament, the European Court of Auditors and the European Economic and Social Committee. His research largely focuses on European social and employment policies, EU economic governance, EU budget, social investment and comparative welfare state.

Dr. Sebastiano Sabato is a senior researcher at the Brussels-based research institute European Social Observatory (OSE), where he has been working since 2014. Previously, he worked as a postdoctoral researcher at the University of Milan and he also collaborated with the Centre on Inequalities, Poverty, Social Exclusion and the City (OASeS) of the University of Antwerp. His research interests include EU socio-economic governance, comparative social policy, 'eco-social policies' and sustainable development, industrial relations.

\section{Authors and Affiliations}

\section{Patrik Vesan $^{1} \cdot$ Francesco Corti $^{2,3} \cdot$ Sebastiano Sabato $^{4}$}

Francesco Corti

francesco.corti2@unimi.it; francesco.corti@ceps.eu

Sebastiano Sabato

sabato@ose.be

1 University of Aosta Valley, Località Grand Chemin 73/5, 11020 Saint Christophe, Italy

2 Department of Social and Political Sciences, Università degli Studi di Milano, Via Conservatorio, 7, 20122 Milan, MI, Italy

3 Centre for European Policy Studies (CEPS), Place du Congrès 1, 1000 Brussels, Belgium

4 European Social Observatory (OSE - Brussels), rue P.E. Janson, 13, 1050 Brussels, Belgium 